\title{
REVIEW. JACQUELINE ELAINE BROWN. 2012. AFRICAN AMERICAN RESPONSES TO AMERICAN PRESIDENTIAL INAUGURAL ADDRESSES. LEWISTON: THE EDWIN MELLEN PRESS. 210 PP. ISBN: 978-0-7734-1317-7.
}

\author{
Antonia Sagredo Santos, UNED ${ }^{1}$ \\ Email: asagredo@flog.uned.es
}

This volume authored by Jacqueline E. Brown is a significant contribution to African American studies since it analyses the African American responses to some American presidential inaugural addresses. It examines presidential inaugural speeches, during Civil Rights and Black Power eras, from the Kennedy administration to President Lyndon B. Johnson, whereas it places presidential inauguration speeches and Civil Rights and Black Power speeches side by side for fully understanding.

The purpose of this book is to position presidential inaugural speeches against speeches by Civil Rights and Black Power leaders in order to show how inaugural addresses exhibit a gap, split or crack in their concern for African American interests, and how black leaders, in turn, respond or interpret the meaning of these gaps in order to reveal this lack of concern.

African Americans have been victims of various forms or erasure in American society, both literally and figuratively. Exploring the political rhetoric of U.S. Presidents during the second half of the $20^{\text {th }}$ century in American government, we discover various types of erasure of African Americans, or, in other words, "gaps" where African Americans are omitted or phased out. This book's purpose is to study that erasure in presidential inaugural addresses.

The argument could be that presidential inaugural speeches are not speeches about race. However, an argument can be made that since a presidential inaugural speech attempts to focus upon the nation's pertinent problems and give some hint as to the solution for those problems, besides seeking to provide some sort of direction for the policies with which a president must grapple, to avoid the race issue is severely negligent. The fact that few previous inaugural addresses before President Johnson deals with race is evidence enough for reason to assume that racism has been a perpetual problem because presidents have always refused to discuss race on major national platforms, thereby contributing to the perpetuation of the problem.

This work will explore how presidential inaugural speeches reflect the overarching mindset of both the government and white Americans, and how, in the postmodern era, this mindset manifests the same sort of African American erasure that has existed since

Date of reception: 29 September 2015

Date of acceptance: 16 October 2015 
Middle Passage. In addition, it will explore the rhetorical engagement black leaders used to respond, to prevent, or to circumvent this erasure. Federal government complicity in the substandard conditions of African American well-being is not a novel revelation.

Since Lincoln's tragic ordeal with the Civil War, only Truman and Eisenhower were forced to openly deal with race issues. Truman's belated focus upon America's race issue might have given Kennedy a clue as to its pertinence as a necessary issue for inclusion in his inaugural address. Truman's focus upon the race issue could have alerted Johnson to the frustrations of African American leaders who had endured "the suffered patience" of hundreds of years of fighting for black rights with little or no progress.

The book is structured into two parts. Part I includes two chapters that analyses John F. Kennedy's and Lyndon B. Johnson's First Inaugural Speeches and some African American responses to them. Part II comprises three chapters with discuss Johnson's Second Inaugural Address and several African American responses to these ideas: "Justice and Change", "Liberty and Change" and "Union and Change". These concepts appeared in Johnson's Second Speech.

The work here reviewed begins with a foreword by Lisa Pertillar Brevard, Core Faculty, at the Walden University (I-IV) and there is an interesting introduction by the author. The first chapter, dealing with the study of Kennedy's well-known First Inaugural Address, 1961, traces some important ideas and concepts. Kennedy's inaugural address reveals a man who, initially, failed to demonstrate recognition of a shadow, or an examined moral consciousness in regards to U.S. race relations. Before the election, in order to carry the South, Kennedy had learned to act, think and feel like a "Southerner", that is, he had to carry on the presidential tradition of rhetorically evading, unless circumstances absolutely required, race issues. On the day of his inauguration Kennedy obviously intended to maintain his "Southern Yankee Son" reputation. Although, further into his administration, he was forced to handle American Civil Rights and desegregation issues as moral crises.

Some black leaders responded to Kennedy's speech by rhetorically including African American domestic problems within many of his proposed agendas and re-interpreting Kennedy perspectives concerning various issues. Martin L. King's Lincoln Memorial address in Washington, D.C., on August 28, 1963, directly addresses Kennedy's Inaugural Address given a year and a half earlier. There are many similarities in the speeches. Both call for "peace", "freedom", "unity", etc. Like Kennedy, King delivered his speech in the nation's capital in front of a monument of recognized distinction. Both speeches were nationally and internationally televised.

In addition to King, there were many, including whites, who answered Kennedy's inaugural calls from an opposing domestic perspective, fighting instead, for black human rights rather than for the rights of those abroad, as though some whites, themselves, were aware of the pertinence of more eminent problems at home than abroad.

The second chapter evaluates the bridge from John F. Kennedy to Lyndon B. Johnson's administration, Johnson's First Inaugural Speech and the African American responses to Johnson's "Global", "Unity" and "Extremist" appeal. Black leaders were wary about whether or not Johnson would continue Kennedy's support of the Civil Rights Bill, as both Kennedy and Johnson could. Johnson was aware of the nation's pre-eminent problems. He does not erase blacks from the landscape of his inaugural vision. President Johnson recog- 
nized King's retaliatory response to Kennedy's evasive inauguration speech and, therefore, chose to respond to King's speech in defense of the slain president. He matches the idea of King's dreaming with dreams of his own, using the repetition of the phrase "the dream".

Most Black leaders wasted no time responding to Johnson's main concerns and they addressed Johnson's three primer issues, "globalism", "extremism" and "national unity". Speeches by African Americans reveal that the prime sector of the planet that was increasingly imperative to African American global interests was the continent of Africa. As for concerns for racial unity, black leaders resigned themselves to the fact that true union between the races in these United States was moving at a claudicant pace. Extremism was the most rhetorically alarming African American leadership riposte, in its rhetorical effectiveness for its attention grabbing capabilities. For instance, what "extreme" to some may not be "extreme" to others.

The third chapter opens with the "Gentleman's Agreement", Johnson's Second Inaugural Address (January 20,1965). This address is considered a $17^{\text {th }}$ century "plain style" of sermon rhetoric, where the form, style and function according to Perry Miller (1956: 332) "reflected in form and style as well as substance the mentality and tastes of Puritans..., and lovers of the Word of God". Just as Puritans preaches had preached about the Covenant to the weary, anxious, and frightened voyagers aboard the Plymouth as they were about to land in the New World, Johnson attempts to ease the fears, white fears, of an America that stands at the dawn of a world of change: "the world will not be the same for our children, or even for ourselves". The part of Johnson's speech entitled "Justice and Change" deals with domestic issues, such as the education, economics, medicine and he acknowledges the disparity between "haves" and "have not". He wows to eliminate economic poverty.

Most African Americans reacted to the notions and ideas in Johnson's "justice and change" message, not only responding directly to economic and social injustice, but, also, attempting to breach the symbolic political, religious and social relationship of covenant theology, the binding metaphor Johnson uses in his second inaugural address.

Chapter four is entirely devoted to the examination of the concepts "Liberty and Change" and deals with, for the most part, global issues that appear in Johnson's Second Inaugural Speech and the African American Leader's responses. Ryan points out how Johnson made these two words "Liberty and Change" the centerpiece of this address, devoting it to foreign policy by using the idea of self-government and the Bill of Rights as paradigmatic examples for other nations, but he did not say that "self-government includes the right of every citizen to vote.

African American adopted a philosophy of political "self-worth" in order to respond to Johnson's second inaugural address. Martin L. King chose to attempt to work within America's established political machine. King's $25^{\text {th }}$ March, 1965 speech, "Our God is Marching On!" is a speech that is centered around the right vote. The three new elements that emerged from the Civil Rights classical base are: the shifting focus of the movement in the South, the spread of the revolution to the North and that, due to the differentiating racial problems of the north and south, the expansion of Civil Rights movement to both northern and southern regions of American expanded their bases within the black community"

The Panther's reaction to Johnson's plea for global political "self-government" was to turn inward to the black community and educate citizens as to how best protect themselves 
from a government on a preoccupied global mission for political freedom and a "Bill of Rights" for everyone worldwide, exclusive of minority citizens within its own borders (Meier, 1971). The Black Panthers' 1966 official program was "We must Destroy Both Racism and Capitalism" (Carson, 1991: 345)

In chapter five she focuses on Johnson's concepts of "Union and Change". Johnson's original second inaugural address intent to propose the idea that, after nearly 400 years, American could become a "beacon" of total equality for everyone, regardless of race. It was a plea for a change of consciousness and heart. He most resembles Abraham Lincoln at that very moment when Lincoln proposed total emancipation for slaves, and delivered the "Gettysburg Address", as he began plans for black inclusion into the American societal mainstream. Both Presidents call upon early American history, whereas they evoke the memories of the nation's forefathers and the democratic ideals upon which America is supposedly based. In addition, both presidents seek to heal their own versions of the strife-inflicted society with words that challenge Americans to peacefully live up to America's idealistic standards and portray a sense of rhetorical urgency, or opportune moment for American citizens to live up to those ideal standards. Yet, the difference between the two presidents, besides the temporal difference, is that Lincoln is addressing white Americans and Johnson seems to be addressing separatist oriented whites and Black Power or Black militant leaders.

Many African Americans, both leadership and the general populace, had lost faith in Johnson's social programs almost as those programs were being simultaneously implemented. The Panthers cleverly repudiate Johnson's second inaugural address by using the tenth edict of their founding philosophy for foregrounding one of the most prominent philosophers on liberty and human rights during American's colonial period, Thomas Jefferson, and his Declaration of Independence.

The final section of this book, the conclusion, opens with President Richard Milhous Nixon's First Inaugural Address (January 20, 1969) and the African American response to this speech. Nixon's first inaugural made it clear that his presidential mission involved both global and domestic efforts. This address draws upon themes of peace, spirit and unification. However, all three of these themes sought to heal the nation, globally and domestically. He encourages global "peace" as an end to the Vietnam War and domestic peace between black and white Americans in regards to racial strife.

African American leaders were as concerned about "law and order" and immediate disengagement from Vietnam as Nixon in his first inaugural address. All African American leadership rhetoric during Nixon's first administration deals with these issues. Nixon claims that "The American dream does not come to those who fall asleep", thereby suggesting that hard work and diligence are the keys to success. The most rhetorical phrase or sense of timing of the average black militant is "The time is now".

Nixon's first term in office was as psychologically confusing and turbulent an era for blacks as the 60 s were for whites, due, for the most part, to Nixon's determined agenda to put everything and everyone back where they once were before the Civil Rights movement.

Considering all this, it can be said that Nixon forewarns Americans, as does Kennedy and Johnson, about the direction in which his administration will go. Ryan (1993: xv-xvi) presents this observation: "The president delivers persuasive speeches to move Congress and the people and to move the people to stir the Congress if it is intransigent". 
Finally the volume showcases and interesting selection of bibliography

Overall, this volume is a very welcome contribution to African American Studies, focusing on Civil Rights. Written with exquisite precision, Brown's book offers an alternative view of some Presidential Inaugural Addresses from a very personnel point of view. In some cases several Black Power Leaders show their opinions, feelings and ideas on Civil Rights issues. This is commendable in its own right since it may serve to promote the study of the African American responses to different issues, concerning Civil Rights. This book undoubtedly provides an invaluable source of information on every facet of African American responses to some American Presidential Inaugural Addresses dealing with Civil Rights Issues. All in all, this volume constitutes a new benchmark in American history.

\section{REFERENCES}

Carson, C. D. J. garrow, G. Gill, V. Harding \& D. Clark Hine, eds. 1991. The Eyes of the Prize Civil Rights Reader. New York: Penguin Press.

Meier, A., E. Rudwick \& F. Broderick. 1971. Black protest Thought in the Twentieth Century. Indianapolis: The Bobbs-Merrill Company, Inc.

Miller, Perry. 1956. Errand into the Wilderness. Cambridge: The Belknap Press of Harvard University Press.

Ryan, H.. 1993. The Inaugural Addresses of Twentieth-Century American Presidents. Connecticut: Praiger. 